\title{
Comparing the Habitat Structure of Red Patas Monkey (Erythrocebus patas) in Marguba and Sepeteri Ranges of Old Oyo National Park, Southwest Nigeria
}

\section{Orimaye J0*}

Ekiti State University, Nigeria

*Corresponding author: Orimaye JO, Department of Forest Resources and Wildlife Management, Ekiti State University, Ado-Ekiti, Nigeria, Tel: 2348038647427; Email: jacob. orimaye@eksu.edu.ng

\section{Research Article \\ Volume 4 Issue 3}

Received Date: March 23, 2020

Published Date: May 13, 2020

DOI: $10.23880 /$ jenr- 16000200

\section{Abstract}

The major problem facing wildlife conservation in Nigeria is the increase rate of loss or modification to the structure of their habitat due to human activity which has greatly affected their survival in their natural environment. This study was done to compare the habitat structure of Red Patas monkey (Erythrocebus patas) in Marguba and Sepeteri Ranges of Old Oyo National Park (OONP), Southwest Nigeria using Total Enumeration Count. Data obtained were analyzed using the Computer PAST program for all indices required. A total of one hundred and one (101) tree species belonging to 32 families were enumerated the study areas with eighty-nine (89) species in 31 families recorded in the Sepeteri range and 72 species in 26 families in the Marguba range and Vitex doniana was the most commonly encountered tree species in both ranges. Furthermore, 70 $(69.31 \%)$ tree species were common to the two sites. Students' t-test indicates that there is no significant difference $(p>0.05)$ in the species composition of the two sites. The effective number of species of 60.95 was computed for the Sepeteri range and 44.26 for the Marguba range. The species dominance was given as 0.02 and 0.03 for Sepeteri and Marguba ranges respectively while the species evenness was 0.68 for Sepeteri and 0.61 for Marguba range. However, the Sorenson's coefficient (SC) of plant species similarity between the two ranges showed a value of 0.70 . Thirty-two (32) families of tree species were recorded in the two ranges with 31 and 26 families in Sepeteri and Marguba ranges respectively. Kolmogorov Simnrrov's test showed no significant difference $(\mathrm{P} \geq>0.05)$ in equal distribution of families in the two sites. The results showed that Sepeteri and Marguba ranges are similar in species composition, family diversity and structural arrangement and indiscriminate felling of woody trees for charcoal and firewood production should be proscribed.

Keywords: Red Patas Monkey; Sepeteri Range; Marguba Range; Vitex Doniana Effective Number of Species

\section{Introduction}

Primate habitats are constantly going through structural and dynamic modifications Birdsey [1] which can affect forest arrangement and species abundance [2]. As a result, most primate species are forced to cope with significant shifts in ecological situations and associated food sources [3]. In this context of rapid human-induced landscape modification across the countries where primate habitat is abundant, improving our knowledge about the ability of these animals to adapt is crucial [4]. The demand for the virgin forest for agricultural activities which causes secondary forests to increase at the expense of primary forests leading to structural and dynamic changes affects the species ecosystem, forest 
composition and species abundance [2].

Patas habitat experiences seasonality change between dry and wet seasons and behaviour of the animal is adjusted between these conditions concerning their proximity along with the usage of available water and also, deforestation and drought are factors that extend the habitat of Patas monkeys. Although Patas Monkey is listed by the IUCN as a species in the group of the Least Concern, the population is now becoming smaller in its known range due to over-exploitation of its natural habitat by man [5]. In the light of the fact that the global population of the animal is not particularly large, increased conservation to the species needs to occur through the proper management of its habitat to prevent the population of the animal from further declining any further.

Marguba and Sepeteri ranges are part of the ranges in Old Oyo National Park that are known to harbour red Patas monkeys as one of the dominant animal species in the past. Nevertheless, the population is constantly declining year in year out due to human activities within the park (Goodwin pers com). Yet, a minimum of attention has been taken through checkmating the rapid deforestation activities, bushfire and other similar human influences going on inside the protected area detrimental to the utilization of the habitat by the animal. The study is therefore initiated to collect information that will lead to the efficient and effective management of the habitat of red Patas monkey in OONP.

\section{Study Area}

Old Oyo National Park (Figure 1) is one of the eight National Parks in Nigeria initially created by Decree Number 36 of 1991 consisting of the amalgamation of the Upper Ogun Forest Reserve and Oyo Ile forest reserve. It is a historicalcultural park because it covers the area that used to be the hub of the Old Oyo Empire of the 17th and 18th centuries [6]. It is located approximately between latitudes $8013^{\prime}$ and 90 $04^{\prime}$ North and longitude 30 53' and 4024' East covering a total land area of 2,512 km. Most of the protected area is covered by plain lowlands between 330 - $508 \mathrm{~m}$ above sea level [7]. Politically, it lies in Oyo State in the Southwest of Nigeria and borders Kwara State in the Northeast. It is surrounded by ten (10) Local Government Areas in Oyo State [7]. Annual rainfall fluctuates between 1600 and $2000 \mathrm{ml}$. Orimaye [8] and a bimodal annual rainfall pattern is experienced between April and July and from September to October, separated by a dry season [9]. The amalgamation of five ranges - Tede, Sepeteri, Marguba, Oyo-ile, and Yemoso ranges forms the Old Oyo national park out of which Marguba and Sepeteri range were purposefully selected (due to the presence of a large population of red patas monkey there) for this research.

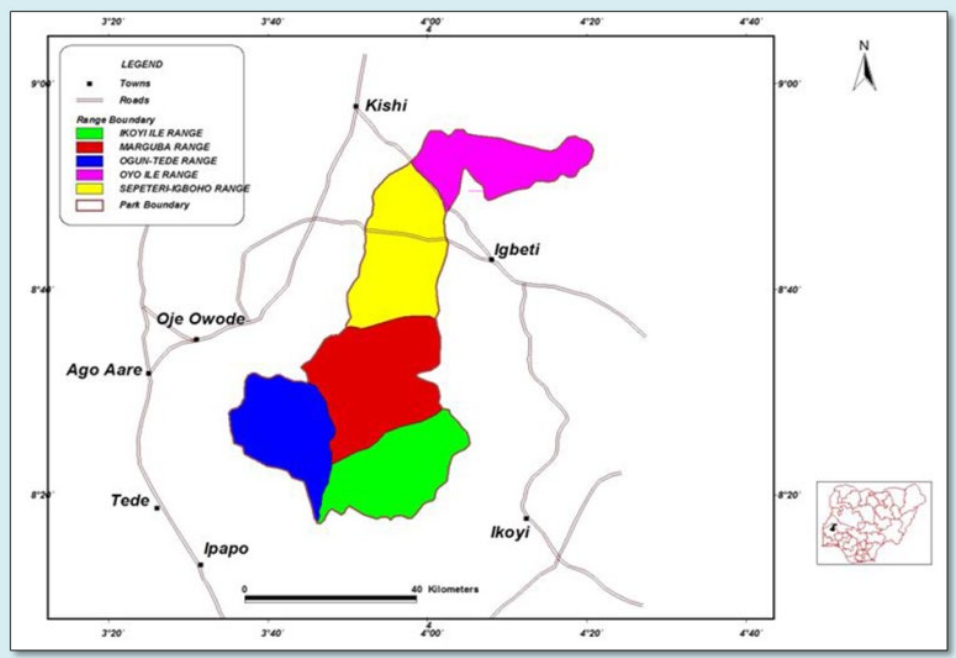

Figure 1: Map of Old Oyo National Park showing it ranges Ogunjinmi [10].

\section{Vegetation}

The vegetation of the OONP has been classified as Southern Guinea Savanna [11]. However, more intense studies by Charter [12] classifies the Southern portion of the vegetation as Forest savanna mosaic with wooded savanna containing the relic of the moist semi-deciduous forest, grading northwards into drier mixed leguminous wooded savanna with a continuous lower stratum of perennial grasses. The vegetation was further analyzed and classified into four broad groups including dense woodland and forest outlier in the southern portion and the Northwest corner, mixed open savanna in the middle and Northeast portions, Outcrop vegetation in the hilly and rocky areas and Riparian 
grassland and fringing woodland and forest vary along major rivers and streams dominated [13]. The team of experts working on the management plan of the park described and recognizes four broad eco-zones to include forest and dense savanna mosaic woodland of the park around Sepeteri axis designated as site A, dense and open savanna woodland mosaic in the central portion of the park, Dense savanna woodland, north of Igbeti-Kishi axis zone $\mathrm{C}$ and Open savanna woodland, North-east of the park (Oyo-Ile sector) [7].

\section{Methods of Data Collection}

Four sample sites for habitat structure surveys were located along already laid transect line around where the animals were sighted and followed at $500 \mathrm{~m}$ intervals giving rise to 80 sample sites across the 2 ranges in the park. 20 of these sample sites (10 sample sites in each of the ranges) were used for habitat analysis [14]. Total Enumeration Count (TEC) of a $25 \times 25 \mathrm{~m}$ area adjacent to the transect line Ogunjemite [15] in each of the 20 sample sites were surveyed. The following data were collected within each sampling quadrants. They include:

i. Total enumeration of all trees above $1 \mathrm{~m}$ height and basal area $\geq 10 \mathrm{~cm}$.

ii. Total enumerations of all the trees species (s) and family in which they belong.

iii. The diameter of all the plants above $1 \mathrm{~m}$ in the height $\geq 10 \mathrm{~cm}$.

\section{Data Analyses}

Data collected was analyzed with the Computer PAST model version $3^{\mathrm{TM}}$ software using a student t-test to compare the sample means between the two ranges. Plant species diversity indices (Shannon diversity indices, Evenness, and species dominance) were calculated using Computer PAST model version $3^{\text {TM }}$. The Sorenson's Coefficient (SC) of overlapping or similarity in diversity was computed using

Sorenson's coefficient $(\beta)=2 c /(S 1+S 2)$

Where $\quad \mathrm{C}=$ the number of species in the two study areas

$\mathrm{S} 1=$ Total number of species found in community 1

S2 $=$ Total number of species found in community 2

The Effective Number of Species = exponential of Shannon diversity index $\{\exp (\mathrm{HSh})\}$, and the results were displayed using frequency tables, percentages and bar charts.

\section{Results}

\section{Tree Species Compositions}

Oyo National Park (OONP) is presented in Appendix 1. One hundred and one (101) tree species belonging to 32 families were enumerated in Sepeteri and Marguba ranges. Eightynine (89) species in 31 families were recorded in the Sepeteri range. The species most frequently encountered include
Vitex doniana (Verbenaceae) with 23 stands followed by Pterocarpus santalinoides (Fabaceae) and Bombax costatum (Bombaceae) with 13 tree species each and Anogeissus leiocarpus of Combretaceae family with 12 individuals. Furthermore, 72 species in 26 families were recorded in the Marguba range with Vitex doniana (Verbenaceae) being the most encountered plant species (33 individuals), followed by Berlinia grandiflora (Caesalpinioideae) and Anogeissus leicocarpus (Combretaceae) with 23 and 19 tree species respectively. Some of the commonly encountered plant species in the two ranges include Afzelia africana, Albizia adianthifolia, Albizia malocophylla, Alchornea cordifolia, Allophylus africanus, Anogeissus leiocarpus, Cola cordifolia, Cola laurifolia, Combretum fragrans, Cordia sinensis, Crossoptesys febrifuga, Cussonia arborea, Daniellia oliveri, and Detarium microcarpum, etc. A total of 70 tree species representing $69.31 \%$ were common to the two sites. Students' t-test indicates that the species composition of the two sites was not significantly different $(p>0.05)$ from each other. In all, 362 stands of woody tree species were enumerated in Sepeteri range while Marguba range recorded 333 stands while Vitex doniana was the most commonly encountered woody species both in ranges.

\section{Diversity Indices of Plant Species}

Table 1 shows the diversity indices of plant species in the range of Red Patas monkey in OONP. Shannon Wiener's indices of species diversity were given as 4.11 which gives the values of the Effective number of species to be 60.95 for the Sepeteri range and 3.79 (Effective number of species $=44.26$ for the Marguba range. The indices of species dominance were given as 0.02 and 0.03 for Sepeteri and Marguba ranges respectively (Table 1). The computed values of species evenness were 0.68 for Sepeteri range while Marguba range had 0.61 The Sorenson's coefficient (SC) of plant species similarity between the two ranges showed a value of 0.70 $(70 \%)$.

\begin{tabular}{|c|c|c|}
\hline Indices & Sepeteri & Marguba \\
Taxa_S & 89 & 72 \\
\hline Individuals & 362 & 333 \\
\hline Dominance_D & 0.02 & 0.03 \\
\hline Shannon_H & 4.11 & 3.77 \\
\hline Evenness_e^ $\mathrm{H} / \mathrm{S}$ & 0.68 & 0.61 \\
\hline Sorenson's coefficient & 0.70 & \\
\hline
\end{tabular}

Table 1: Diversity indices of plant species in Sepeteri and Marguba ranges in OONP.

\section{Families of Woody Tree Species Composition}

Appendix 2 showed the diversity in Families of tree 
species in Sepeteri and Marguba ranges at OONP. Thirty-two (32) families of tree species were recorded in the two ranges with 31 and 26 families in Sepeteri and Marguba ranges respectively. The family with the highest occurrence was Caesalpinioideae in both ranges with 10 species each which is closely followed by family Moraceae with 9 species in Sepeteri range while Anacardiaceae, Euphorbiaceae, and Moraceae had the highest occurrence of 6 species each in Marguba range. However, ten families which include Annonaceae, Araliaceae, Boraginaceae, Celasfraceae, Dilineniaceae, Ebenaceae, Flacourtiaceae, Hyrnenocardioceae, Palmae, Simaroubaceae, and Teliceae were represented by only one species in Sepeteri range while 6 families, including Araliaceae, Boraginaceae, Celasfraceae, Ebenaceae and
Flacourtiaceae also had 1 species representation each in Marguba range. Kolmogorov Simnrrov's test showed no significant difference $(\mathrm{P} \geq>0.05)$ in equal distribution of families in the two sites.

\section{Structure of Tree Species: Tree Height}

The structure of the tree species in Sepeteri and Marguba ranges where Red Patas monkeys are abundant in Old Oyo National Park showed that the mean tree height at the Sepeteri range was $10.35 \pm 2.32 \mathrm{~m}$ and that of Marguba range was $9.71 \pm 0.91 \mathrm{~m}$. Plants within the height of 9 and $12 \mathrm{~m}$ were the commonest between the two ranges (Figure 2). T-test of tree heights between these two ranges showed no significant difference $(P \geq>0.05, p=0.6801)$ in mean height.

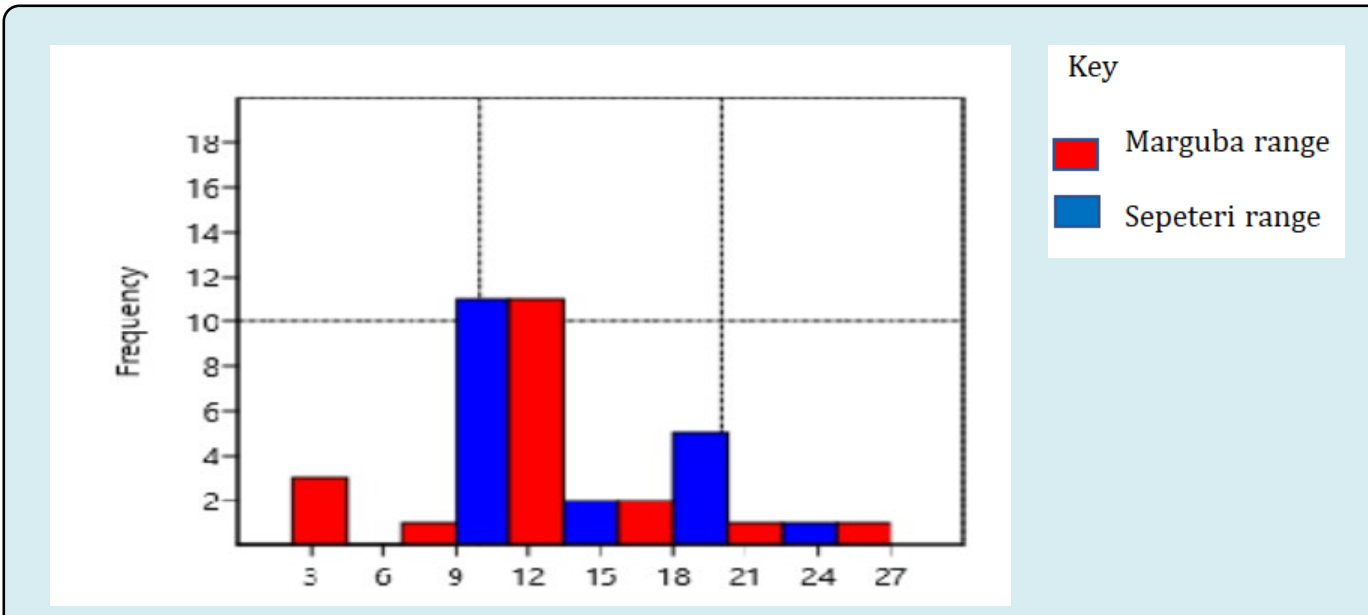

Figure 2: Height distribution of tree species in the habitat of Red Patas monkey at OONP.

\section{Diameter at Breast Height Distribution}

The mean Diameter at Breast Height (dbh) of the tree species at the Sepeteri range was $34.3 \mathrm{~cm}$ while that of Marguba was $33.5 \mathrm{~cm}$. T-test showed that there is no significant difference $(\mathrm{P}>\geq 0.05 ; \mathrm{p}=0.4571)$ between the $\mathrm{dbh}$ of the two study sites. Furthermore, the dbh distributions showed that tree species with $\mathrm{dbh}$ of $10 \mathrm{~cm}$ to $35 \mathrm{~cm}$ were the commonest (Figure 3).

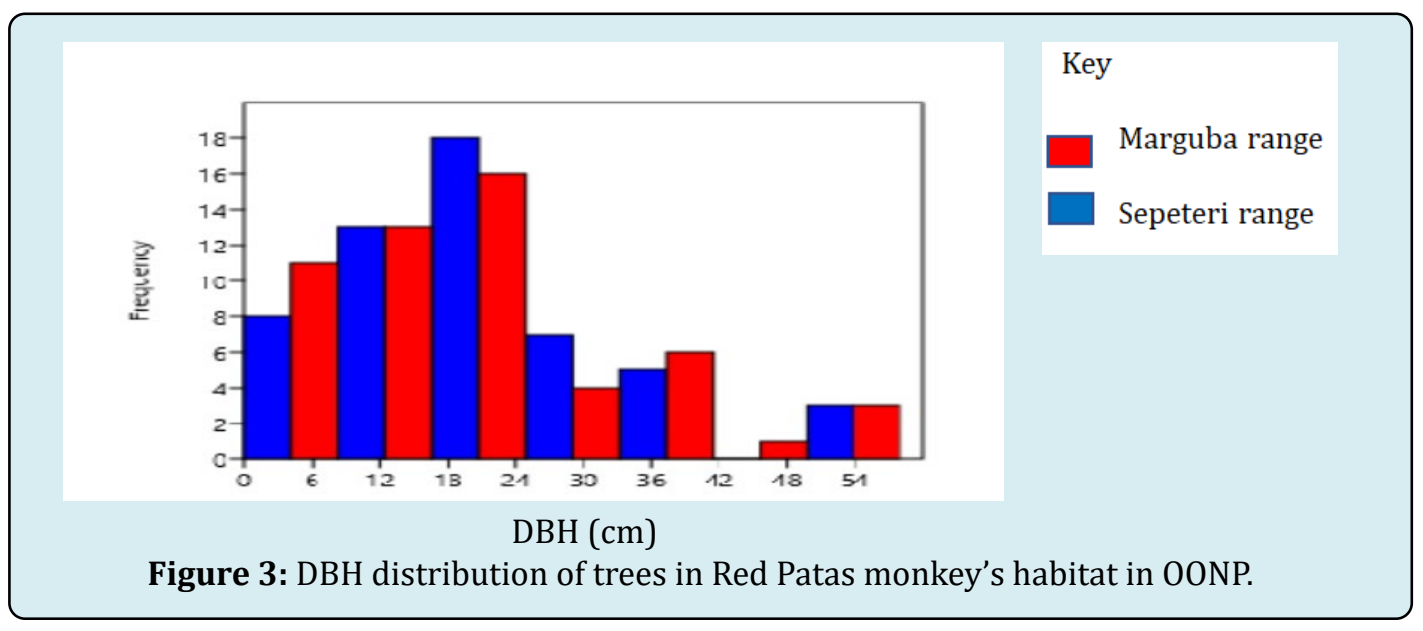




\section{Discussion}

Sepeteri and Marguba ranges of Old Oyo National Park's vegetation were similar in terms of specie composition and structure which may be a factor for the presence of red Patas monkey in these areas. The important families of the plant in the ranges include Caesalpinioideae, Euphorbiaceae, Mimosoideae, Moraceae, and Sterculiaceae. Parkia biglobosa and Vittelaria paradoxa which belongs to the family Leguminosae are an essential component of the food of red Patas monkey. These monkeys are folivores and therefore their distributions are bound to be influenced by plant species that formed their primary food source. Ogunjemite [16] reported that higher numbers of leguminous plants are usually reported in the habitat of folivorous monkeys. Sorenson's coefficient of community similarity obtained in this study showed that the key plant species of the habitats are about $70 \%$ similar which is an indication that these sites may harbour similar animal species. It is therefore established that plant diversity and vegetation structure are strong factors influencing the distribution of red Patas monkey in OONP. This assertion was further corroborated by the findings of Moffat [17], Ogunjemite [16,18] that vegetative arrangement and species diversity of some key families could be a determining factor in the management of arboreal animal especial primate species of which red Patas monkey is one. Although red Patas monkeys are arboreal animals, they spend most of their time on land. The mean height and the mean dbh of the woody tree species in the two ranges showed no significant difference from each other which is further proof of the similarity existing between the two ranges. This observation agrees with the assertion of Bright and Morris [19], Ogunjemite [16,18] that the architectural arrangement of vegetation influences the distribution of associated fauna species [20-22].

Red patas monkey were common species in OONP in the past, but their population is gradually decreasing as a result of degradation of the forest environment brought about by human activities

\section{Conclusion and Recommendation}

The results established that Sepeteri and Marguba ranges where the study was carried out are similar in species composition, family diversity, and structural arrangement. The family Combretaceae, Caesalpinioideae and Fabaceae, are very important components of the habitat of red Patas monkey in OONP. The management of red Patas monkeys in the park should consider the protection of these families of tree species in the habitat for the effective conservation of the animals. The following recommendations are made based on the findings of this study which are: -

I. Illegal and Indiscriminate felling of woody trees for charcoal production and firewood production should be prohibited.

II. The anti-poaching patrol team of the National Park should be strengthened to be able to do their job more effectively.

\section{References}

1. Birdsey R, Pregitzer K, Lucier A (2011) Forest carbon management in the United States: 1600-2000. J Environ Qual 35: 1461-1469.

2. Wright SJ (2005) Tropical forests in a changing environment. Trends Ecol Evolution 20(10): 553-560.

3. Marsh LK, Chapman CA, Arroyo-rodriguez V (2013) Primates in fragments 10 years later: once and future goals. In: Marsh LK, Chapman CA (Eds.), Primates in fragments: complexity and resilience. New York, NY: Springer New York, pp: 503-523.

4. Corlett R (2011) How to be a frugivore (in a changing world). Acta Oecologica 37(6): 674-681.

5. IUCN (2008) Erythrocebus patas. The IUCN list of Threatened Species.

6. Old Oyo National Park (1995) Management Plan for Old Oyo National Park.

7. Afolayan TA, Anadu PA (1997) Preliminary observations on the ecology and domestication of Grasscutter. J Institute Animal Technicians (1): 31-38.

8. Orimaye JO (2019) The Feeding Ecology of Red-Patas Monkey (Erythrocebus Patas) in Old Oyo National Park, Southwest Nigeria. J Ecol \& Nat Resour 3(3): 000167.

9. Mengistu DA, Salami AT (2007) Application of Remote Sensing and GIS Inland Use/Land Cover Mapping and Change Detection in a Part of South Western Nigeria. African J Environ Sci Technol 1(5): 99-109.

10. Ogunjimi AA, Emelue GU, Salaudeen HO, Ojo OA (2016) Migration Dynamics and perceived causes of conflicts between communities and Old Oyo National Park, Nigeria. Nigerian J Agriculture Food Environment 12(3): 147-154.

11. Keay RW (1959) An Outline of Nigerian Vegetation. $3^{\text {rd }}$ (Edn.), Lagos, Nigeria: Federal Government Printer.

12. Charter JR (1970) Vegetation Ecological Zones. Unpublished M. Sc Federal Department of Forestry, Ibadan.

13. Geerling C (1973) Vegetation of Upper Ogun and Old 
Journal of Ecology and Natural Resources

Oyo Game reserve, Department of Forestry, University of Ibadan.

14. Ogunjemite BG, Afolayan TA, Agbelusi EA (2005) Habitat structure of chimpanzee community in Ise Forest Reserve, Ekiti State, South-western Nigeria. African Journal Ecology 43(4): 396-399.

15. Ogunjemite BG (2006) Trends in the Chimpanzees of Kukuruku Hills: Indication of Extinction in the Population of Chimpanzees of South-west Nigeria. Nigerian J Forestry 36(2): 116-125.

16. Ogunjemite BG, Ajayi B, Agbelusi EA (2007) Habitat structure of chimpanzee communities in Nigeria: a comparison of sites. Acta Zoological Sinica 53(4): 579588.

17. Moffat C, McNeill S, Morton A (2005) The quantification of habitat architecture for explanation of arthrodod assemblage patter: a comparison of two methods. Community Ecology 6(1): 83-91.

18. Orimaye JO, Ogunjemite BG, Agbelusi EA (2017)
Density and Abundance of the RedCapped Mangabey (Cercocebus Torquatus) In Omo Biosphere Reserve and Idanre Forest Reserve, South Western Nigeria. MOJ Proteomics Bioinform 5(2): 63-67.

19. Bright PW, Morris PA (1990) Habitat requirement of dormice Muscardinus avellamauis in relation to woodland management in Southwest England. Biological conservation 54: 307-326.

20. Ayodele IA (1988) Ecological Basis for the Management of Old Oyo National Park. Ph.D. Thesis, University of Ibadan, Ibadan.

21. Nash LT, Whitten PL (1989) Preliminary observations on the role of Acacia gum chemistry in Acacia utilization by Galago senegalensis in Kenya. American J Primatol 17(1): 27-39.

22. Amoah M, Wiafe E (2012) Livelihoods of Fringe Communities and the Impacts on the Management of Conservation Area: The Case of Kakum National Park in Ghana. International Forestry Review 14(1): 1-14. 